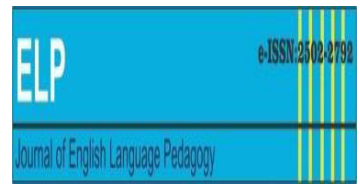

JOURNAL OF ENGLISH LANGUAGE PEDAGOGY

Vol. 5, No. 2, July 2020, pp. 11-20

\title{
CHARACTER VALUES ANALYSIS OF STUDENTS' ENGLISH HANDBOOK THINK GLOBALLY ACT LOCALLY
}

\author{
M. Happy Nur Tsani \\ Universitas Nahdlatul Ulama Purwokerto \\ Email : mhappynur2@gmail.com
}

\begin{abstract}
Character building is major issue in education. The concept of national character building refers to an effort to build nation's character as stated in National Education system Decree Number 20 of 2003 chapter 3. National education aims to develop life skill and good character building of human. Thus, as compulsory and newly published handbook with regards to the implication of 2013 Curriculum, the ninth grade students' handbook Think Globally Act Locally should promote character values. This study aimed at exploring character values promoted in the handbook. The document analysis as one of branches in qualitative method is used in this study. The finding of this study reveals that the handbook has already promoted national character building.
\end{abstract}

Keywords: Handbook, Character Values

\section{INTRODUCTION}

Character building is an important and current isue in our education. The existence of many social matter such as corruption issues, rape, free sex, bullying, terrorism and horizontal conflict has lowered sense of character education. The development of personal emotion is the impact process of character education. Spiritually, and personality. Therefore, character or moral education as a part of an effort to build the nation's character which is also called National character building.

Every subject, should be integrated with national character building. Teachers should not not only transfer cognitive skill, but also character input. They need to integrate the character building in English language learning. The integration can be done through the material, media and learning activities.

Indeed, there are some studies regarding the integration of character bulding in English language learning. Jamaludin (2013) conducted a research to investigate the integration of character values in English language teaching especially in teaching narrative. His study 
explored the integration of character values focused on narrative text. In addition, Suherman (2015) investigated how students comprehend moral values learned together through narrative text models. From the previous studies, it can be inferred that the character building has been integrated in teaching and learning process. However, all of the studies only focus on narrative text teaching material. Therefore, the questionis "can the character values be integrated in other teaching material?". To nswer this question, a study on the integration of character values in teaching material, especially students' English handbook is needed.

A language classroom always needs language teaching handbooks. Brown (2001, p. 136) states that handbook gives the most common material support for language instruction. Furthermore, Harmer (2007, p. 182) states the handbook is used to help students and to provide structure and direction for teachers in teaching. It also helps to attract students in discovering the topic material they will learn.

Equally important, Richards (2001, p. 256) states that handbook is actually the guide of learning structures. Without handbook, a language program may have no core. Language learner may not be able to follow the syllabus and the structures of learning which has systematically been planned and developed in the curriculum.

In relation with character education, it is expected that the value of character and culture in Indonesia are reflected from the syllabus, lesson plans, instructional materials, as well as the teaching practices (Kemdikbud, 2011). As an instructional material, a handbook is the primary input to the language learning process in the classroom. Richards (2001, p. 251) argues that instructional material is a key component of most language programs in curriculum. So, teachers should utilize a proper instructional material to enhance the quality of teaching and learning process.

Course book as one of instructional resources to achieve goals and ideas that have already been recognized in terms of students need (Cunningsworth, 1995, p. 7) . The teacher can select appropriate materials in course book which is suitable for their students' needs or develop their own materials. Nevertheless, there are still many teachers who depend much on course book because they are unlikely to make their own teaching materials. Thus, they just use the course book as the main resource for their teaching activities. Lie (2007) notes a study conducted by Supriyadi indicates that handbooks are still trusted by Indonesian teachers which makes the class handbook-driven. Thus, before choosing a handbook, the content of handbook must be evaluated. Cunningsworth (1995, p. 22) declares that teachers

\section{Copyright @ 2020, ELP, ISSN 2656-6451 EISSN 2502-2792}


development need course book analysis and evaluation to help teachers gaining good understanding into the nature of material.

Moreover, Cunningsworth (1995, pp. 15-17) categorizes four criteria for evaluating handbooks, especially course book. The first criterion is that handbooks should correspond to learner's need. It means that the aims and objectives of the language learning program should be represented in the handbook. Secondly, the uses (present or future) that learners will make of the language should reflected in the handbooks. The handbook selection will support students to practice language effectively for their own purposes. Third, handbooks should take description of students' need and facilitate learning process. The last criterion, handbooks should have clear role as support to learning, such as teacher mediate between the target language and the learner.

In addition, Depdiknas has given the guidance to choose teaching materials in general. Depdiknas in Abidin (2012, pp. 49-50) explains how to select instructional materials to be aware of the teacher in some principles. They are the principle of relevance; it means that the achievement of standards and basic competencies should have relevance to learning materials. The next principle is the consistency of the basic competencies that must be mastered by students with teaching materials. For example, the students must master four different basic competencies, then the teacher should also give teaching materials which include four kinds. The last principle is the principle of adequacy; the teaching materials will be helpless to achieve standards of competence and basic competences if they do not adequate. On the contrary if it's too many it will be a waste of time and energy.

In accordance with Character-based Integrated Curriculum 2013, the goverment provides an English handbook for ninth grade of junior high school students entitled Bahasa Inggris: Think Globally Act Locally. It is intended to facilitate the achievement of the aim of English subject in the 2013 curriculum. Additionally, this book will be used by all junior high schools in Indonesia, since all schools in Indonesia are starting to implement the 2013 curriculum .

After knowing that character building is very important to integrate in teaching learning process, then in this study, the writer wants to investigate the integration of character building in language teaching, especially in teaching learning material. This study focuses on exploring character values promoted in the students' English textbok for the ninth grade Think Globally Act Locally with the reason that the book shows the need for learners to

\footnotetext{
13 Copyright @ 2020, ELP, ISSN 2656-6451 EISSN 2502-2792
} 
develop global thinking and keep nation and character values of Indonesian culture related to its title "Think Globally Act Locally”.

\section{METHOD}

Qualitative approach is used in this study to describe data obtained from the handbook. This study employed document/content analysis technique to afford answers that relate to the research questions. The analysis focuses on the character values promoted in the handbook. The analyzing technique was conducted by investigating the frequency of character values in the handbook. The result from the frequency of character values then used as basic data for interpretation. The result and discussion are presented in words rather than numbers, number refers to counted result in this research is a way used to infer the phenomena emerge on the handbook in order to perceive the result. As Miles, Huberman, and Saldana (2014) proposed that data in the form of words is focused in qualitative research. This study aims to analyze image, texts and the messages implied from those images and texts to explore the character values that are represented in the handbook. It will be conducted through content analysis which according to Manion and Morrison (2007, p. 475) refer to the process of summarizing and interpreting written data for the purpose of identifying specified characteristics of the material (Ary, Jacobs, Sorensen, \& Razavieh, 2010, p. 457).

The source of data in this study is the ninth grade students' English handtbook Think Globally Act Locally, while the data in this study are images and texts contained in the handbook. The images are animated human images that possessed particular character value. Meanwhile the texts are written utterances that function as learning instructions, texts model, and student's exercises in the handbook. To facilitate data collection about the content of handbook related to its images and texts, this study uses content analysis sheets as the instrument.

\section{FINDINGS AND DISCUSSION}

This segment discusses and interprets the findings related tobe existed theories of national character building. This segment is divided into two sub segement. The first sub segment elaborates the discussion on character values which are promoted in handbook and the second segment is the discussion on representation of those character values in handbook.

The result of identifying data analysis showing that character values appear in the students' English handbook Think Globally Act Locally. The character values are relevant with what Kemendiknas (2010) states that there are eighteen character values should be

\footnotetext{
14 Copyright @ 2020, ELP, ISSN 2656-6451 EISSN 2502-2792
} 
integrated into lessons. Those eighteen character values are religiosity, honesty, tolerance, discipline, hard working, creativity, independence, democracy, curiosity, nationalism, patriotism, achievement orientation. Friendship/ communication, peace loving, fondness of reading, environmental awareness, social awareness and responsibility. It means that the handbook can be used as a source and guidance in the character education, for the ninth grade of junior high school.

From those 18 character values, hard working, curiosity, friendship or communication are the most dominant Thus, because the handbook provides the students mostly with group completion tasks. Those character values are integrated in group work activities. The benefit of this group work is the teacher can integrated more than one character value. This activity will stimulate students to have a good frienship or communication, then they also will have strong desire to finish the task. In addition, it will improve students curiosity. Those dominant character values shows that the handbook wants to raise the students hard working, curiosity and friendship or communication. Meanwhile, democracy, tolerance and responsibility stand in the lowest position. Those character values still need to be integrated more in the handbook. It can be done by the teachers by integrating those character values in discussion section, then responsibility can be integrated in finishing the task in the handbook.

In relation with character education, the handbook has already reflected character values and culture in Indonesia. Thus in line with what Kemdikbud (2011) explains that it is expected that the value of character and culture are reflected from the syllabus, lesson plans, instructional materials as well as the teaching practices. The teaching materials of the students' English handbook Think Globally Act Locally can be used to moral guidance in specific style of moral teaching, as stated by Kohn (1997), character education is generally defined as anything from "values clarification" worth for citizenship and moral guidance, which further it specificaly refers to a specific style of moral teaching.

The indonesian goverment has already promoted national character building through the curriculum, and this effort is supported by the handbook industry. The handbook is published by the Ministry of education as the compulsory source for all ninth grade students in Indonesia for 2013 curriculum implementation. As a consequence the handbook should be relevant with the development of the curriculum. As Darsih (2014) notes that restoring character education and improving students' creative thingking are the main reasons of the 2013 curriculum development. It is presumed that the current curriculum aims to build an

\footnotetext{
15 Copyright @ 2020, ELP, ISSN 2656-6451 EISSN 2502-2792
} 
excellent character for the nation which will be strengthen its identity by paying more attention to character building.

In the case of 2013 curriculum, the result shows that the students' English handbook Think Globally, Act Locally has already promoted the 18 character values described by Kemendiknas. It can be said that the handbook is relevant to 2013 curriculum although some character values still need to be integrated more such as democracy, tolerance and responsibility. This in line with Poerwati (2012) who mentioned that the orientation of 2013 curriculum is the achievement of balanced competence between attitude, skill and knowledge. In addition, the authors also want to support national character building through the examples found in the handbook. Those representations also reveal how the goverment intends to build character value of the learners in the handbook. Further more, 2013 curriculum aims to improve the quality of processes and outcomes of education, which leads to the formation of students' good character (Mulyasa, 2013, p. 7) .

Another Character values that are found excluding 18 character values described by Kemendiknas shows that the handbook also integrate additional character values that also exist in the society. Those character values form students' character to create a better society. As Philips in Mu'in (2011) argues that thinking, attitudes, and behaviors are also a collection of character values.

Having analyzed the data, the writer found that the character values represented both explicitly and implicitly in the handbook. Explicit representations were found in a way what the writers deliberately mentioned that a particular chapter in the handbook. Integrating character values for education is necessary as stated by Chapman (2011) that the main idea of character education is to improve the behavior or attitudes of students at school. Then, any implicit representations were found in the handbook which were not intended by the authors. Meanwhile, The students are expected to master all lessons that they learn and be able to practice the good thing and the bad thing. Previously, the responsibility of character educations refers to religion's teachers, civic education and guidance and counseling teachers. However, teaching and learning process in 2013 curriculum requires all teachers to integrate character education.

Basically, the integration of character education into classroom curriculum should be achieved with the use of activities and class meetings. Equally important, the English teacher can integrate character values in the students' English handbook as teaching material. Since the most common of material support for language instruction come through handbook.

16 Copyright (C) 2020, ELP, ISSN 2656-6451 EISSN 2502-2792 
The integration of character values in the handbook found directly and indirectly. As stated by Zuchdi (2008, p. 5) notes that the integration of character values can be done diretly or indirectly. Thus, the integration of character education can be categorized into explicit (direct) and implicit (indirect). The explicit integration makes learners more easily understand character values contained in the handbook. On the contrary, implicit integration train learners' logical reason and imagination in order to find and understand the messages of the character values contained in the handbook.

Based on the role of handbook in English Foreign Language Classroom for students. Hutchinson and Torres (1994) mentions that handbook should provide the basis of a dialogue. The students' English handbook Think Globally Act Locally has already provided some dialogue as the stucture to control the instructional design. Mostly all chapters in the handbook presented dialogue as part of students' activities in the teaching and learning process.

Based on the criteria of a good handbook Dat (2008) proposes a positive features of a handbook should include a national identity. The finding shows that the national character building has been promoted in the handbook. The national identity in the handbook can be promoted through accounts of daily values. The materials in the handbook refers to the target should be achieved by learners. In this case, the character values stated in National Character Building are highly available in the students' English handbook Think Globally Act Locally. It is appropriate to an effort to build nation's character. Furthermore, the handbook provides many activities, reading and explanation. Thus, in line with Hutchinson and Torres (1994, p. 317) notes that the handbooks are needed in classroom lesson through varied activities, reading and expalanation.

The integration of character values can be done implicitly and explicitly in the teaching and learning process. The option of integrating character values is relevant with what Kemendiknas (2010) states that integrating character values in a lesson is the gist of character education. The result of study shows that the character values in the handbook are represented both explicitly and implicitly. Moreover, the implicit representation is more dominant in the handbook. Teachers and students are expected to accept the message of the handbook given by the author by knowing the character values are mostly delivered implicitly, the.

The previous study conducted by Jamaludin (2013) and Suherman (2015), only focus on the integration of character value in narrative text. Jamaludin explored the integration of

17 Copyright @ 2020, ELP, ISSN 2656-6451 EISSN 2502-2792 
character values on teaching narrative as text widely used by adolescents. In addition the study conducted by Suherman investigated how the students comprehend moral values learned together thorugh learning narrative text models. From those previous studies, it can be inferred that the character values can be integrated in teaching and learning process. Then, this study reveals that the integration of character values can be done in all teaching material including students' English handbook.

\section{CONCLUSION AND SUGGESTION}

Based on the findings and discussions, character values are found in the textbok covering eighteen character values described by Kemendiknas. Those character values are

religiosity, honesty, tolerance. discipline, hard working, creativity, independence, democracy, curiosity, nationalism, patriotism, achievement orientation, friendship or communication, peace loving, fondness of reading, environmental awareness, social awareness and responsibility. From those eigthteen character values hard working, curiosity, friendship or communication are the most dominant. Meanwhile, democracy, tolerance and responsibility stand in the lowest position.

The dominant of those character values implies that the handbook wants to raise students' frienship or communication, hard working and curiosity. Furthermore, the dominant character values are mostly found in group work activities. The teaching materials in this handbook cover more something new for students. This may imply that the priority of the handbook is related to exploring knowledge and human interaction.

Furthermore, character values in the handbook are represented both explicitly and implicitly. The implicit representation is more dominant in the handbook. This is in accordance with the role of teacher in all activities of teaching and learning process. Regarding the findings and discussion of this study, the teacher should integrate character values in the teaching and learning process. Related to the frequency of character values, teacher may add, reduce or adapt which material and activities that can support character values.

\section{REFERENCES}

Abidin, Y. (2012). Pembelajaran Membaca Berbasis Pendidikan Karakter. Bandung: PT Refika Aditama.

\section{Copyright @ 2020, ELP, ISSN 2656-6451 EISSN 2502-2792}


Ary, D., Jacobs, L. C., Sorensen, C., \& Razavieh, A. (2010). Introduction to research in education eight edition. Wadsworth: Cengage Learning.

Brown, H. D. (2001). Teaching by Principles- An Interactive Approach to Language Pedagogy. New York: Longman.

Chapman, A. M. (2011). Implementing character education into school curriculum. ESSAI, 9(1), 11.

Cunningsworth, A. (1995). Choosing Your Coursebook. Heneimann: Macmillan Education.

Darsih, E. (2014). Indonesian EFL Teachers' Perception On the Implementation of 2013 English Curriculum. English Review : Journal of English Education, 2, 192-199.

Dat, B. (2008). ELT Materials used in Southeast Asia. In B. Tomlinson English Language learning materials: A Critical Review. Continuum (London), 263-280.

Harmer, J. (2007). The Practice of English Language Teaching Essex: Pearson.

Hutchinson, T, \& Torres, E. (1994). The Handbook as Agent of Change. ELT Journal, 48(4), 315-328.

Jamaludin. (2013). The Integration of Character Values In Teaching Narrative Text At State Senior High School of Pamekasan. State University of Surabaya, Surabaya.

Kemdikbud. (2011). Panduan Pelaksanaan Pendidikan Karakter. Jakarta.

Kemendiknas. (2010). Pengembangan Pendidikan dan Karakter Bangsa. Jakarta: Kementrian Pendidikan Nasional, Badan Penelitian dan Pengembangan Pusat Kurikulum.

Kohn, A. (1997). How not to teach values: A critical look at character education. Phi Delta Kappan, 78, 428-439.

Lie, A. (2007). Education Policy and EFL curriculum in Indonesia: Between the commitment to competence and the quest for higher test scores. TEFLIN Journal 18 (1), 1-14.

Manion, L. C. L., \& Morrison, K. (2007). Research Methods in Education (6th ed.). New York: Routledge.

Miles, M. B., Huberman, A. M., \& Saldaña, J. (2014). Qualitative data analysis: A methods sourcebook. 3rd.

Mu'in, F. (2011). Pendidikan Karakter-Konstruksi Teoritik \& Praktik-Urgensi Pendidikan Progresif dan Revitalisasi Peran Guru dan Orangtua. Yogyakarta: Ar-Ruzz Media.

Mulyasa. (2013). Pengembangan dan Implementasi Kurikulum 2013. Bandung: PT Remaja Rosdakarya.

19 Copyright @ 2020, ELP, ISSN 2656-6451 EISSN 2502-2792 
Poerwati, L. I. (2012). Panduan Memahami Kurikulum 2013. Jakarta: Prestasi Pustaka Raya.

Richards. (2001). Curricullum Development in Language Teaching. Cambridge: Cambridge University Press.

Suherman, U. (2015). Teaching Moral Values Through Narrative Text Models. The Sate University of Surabaya, Surabaya.

Zuchdi. (2008). Humanisasi Pendidikan: Menemukan Kembali Kehidupan yang Manusiawi. Jakarta: Bumi Aksara. 